\title{
Failure of chronic hyperinsulinemia to suppress pancreatic glucagon in vivo in the rat
}

\author{
PATRICIA L. BrubakeR ${ }^{1}$ \\ Department of Physiology, University of Toronto, Toronto, Ont., Canada M5S IA8 \\ Tsutomu Kazumi ${ }^{2}$ and Tsutomu HiRano ${ }^{3}$ \\ Department of Medicine, University of Toronto, Toronto, Ont., Canada M5S 1A8 \\ AND \\ Mladen VRanic and George Steiner \\ Departments of Medicine and Physiology, University of Toronto, Toronto, Ont., Canada M5S IA8 \\ Received July 16, 1990
}

\begin{abstract}
Brubaker, P. L., Kazumi, T., Hirano, T., Vranic, M., and Steiner, G. 1991. Failure of chronic hyperinsulinemia to suppress pancreatic glucagon in vivo in the rat. Can. J. Physiol. Pharmacol. 69: 437-443.

To determine the effects of chronic hyperinsulinemia on glucagon release, rats were made hyperinsulinemic for 14 days by supplementation of drinking water with sucrose ( $10 \%$; sucrose-fed) to increase endogenous release or by implantation of osmotic minipumps (subcutaneous, s.c.; or intraperitoneal, i.p.) to deliver exogenous insulin (6 U/day). Both s.c. and i.p. rats also had sucrose in the drinking water to prevent hypoglycemia. Plasma insulin levels were significantly elevated in sucrose-fed, s.c., and i.p. rats. However, glucose levels were significantly elevated in sucrose-fed rats only. Surprisingly, plasma glucagon concentrations were elevated in i.p. and s.c. rats and were not suppressed in sucrose-fed rats. Inverse relationships were found between the plasma levels of insulin and glucose $(n=65 ; r=-0.42, p<0.0001)$ and between glucose and glucagon $(n=73 ; r=-0.46, p<0.0001)$. However, unexpectedly, a positive correlation between insulin and glucagon $(n=65 ; r=0.47, p<0.0001)$ was established. As suppression of plasma glucagon levels below basal was not observed in any of the hyperinsulinemic or hyperglycemic rats, we wished to establish further whether pancreatic glucagon release could be suppressed below basal levels in the rat by another means. Thus, high doses of somatostatin $\left(50-100 \mu \mathrm{g} \cdot \mathrm{kg}^{-1}\right.$. $\min ^{-1}$ ) were infused for $45 \mathrm{~min}$ into normal rats without or with a concomitant hyperinsulinemic, hyperglycemic glucose clamp. Somatostatin fully suppressed insulin, but although plasma glucagon levels were decreasd by somatostatin infusion relative to saline-infused animals, there was still no suppression below basal levels. Thus, the rat $\mathrm{A}$ cells are less sensitive to somatostatin than are those of other species. The results of this study demonstrate that chronic endogenous or exogenous hyperinsulinemia does not inhibit glucagon secretion, even in the presence of hyperglycemia. Factors other than insulin may therefore play an important role in the regulation of the pancreatic A cell in the chronic hyperinsulinemic rat.
\end{abstract}

Key words: glycemia, insulin, glucagon, somatostatin, very low density lipoprotein.

Brubaker, P. L., Kazumi, T., Hirano, T., Vranic, M., et Steiner, G. 1991. Failure of chronic hyperinsulinemia to suppress pancreatic glucagon in vivo in the rat. Can. J. Physiol. Pharmacol. $69: 437-443$.

Pour déterminer les effets d'une hyperinsulinémie chronique sur la libération de glucagon, des rats ont été rendus hyperinsulinémiques pendant 14 jours, soit par l'addition de saccharose à l'eau de breuvage (10\%; nourris au saccharose (NS)) pour augmenter la libération endogène d'insuline, soit par l'implantation de minipompes osmotiques (sous-cutanées (s.c.) ou intrapéritonéales (i.p.)) pour transmettre l'insuline exogène $(6 \mathrm{U} / \mathrm{j})$. Du saccharose a aussi été ajouté à l'eau des rats i.p. ou s.c. pour prévenir l'hypoglycémie. Les taux d'insuline plasmatique ont été significativement élevés chez les rats i.p., s.c. et NS. Toutefois, les taux de glucose n'ont été significativement élevés que chez les rats NS. Étrangement, les concentrations de glucagon plasmatique ont été élevés chez les rats s.c. et i.p., et n'ont pas été supprimés chez les rats NS. Des relations inverses ont été observées entre les taux plasmatiques d'insuline et de glucose $(n=65 ; r=-0,42, p<0,0001)$ et entre ceux de glucose et de glucagon $(n=73 ; r=-0,46, p<0,0001)$. Toutefois, une corrélation positive entre l'insuline et le glucagon $(n=65 ; r=0,47, p<0,0001)$ a été établie. Aucune suppression des taux de glucagon plasmatique sous le niveau de base n'ayant été observée chez aucun des rats hyperglycémiques ou hyperinsulinémiques, nous avons voulu vérifier s'il était possible de supprimer par d'autres moyens la libération de glucagon pancréatique sous les niveaux de base chez le rat. Ainsi, de fortes doses de somatostatine $\left(50-100 \mu \mathrm{g} \cdot \mathrm{kg}^{-1} \cdot \mathrm{min}^{-1}\right)$ ont été perfusées pendant 45 min à des rats normaux avec ou sans clamp glucosique hyperglycémique, hyperinsulinémique. La somatostatine a totalement supprimé l'insuline; toutefois, bien que les taux de glucagon plasmatique de ces rats aient été diminués par la perfusion de somatostatine par rapport à ceux des animaux perfusés de solution salée, il n'y avait toujours pas de suppression sous les taux de base. Ainsi, les cellules A des rats sont moins sensibles à la somatostatine que celles des autres espèces. Les résultats de cette étude

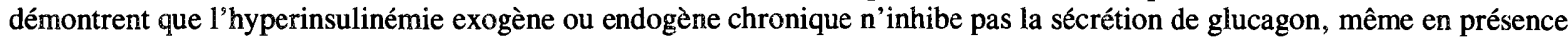
d'hyperglycémie. Des facteurs autres que l'insuline pourraient par conséquent jouer un rôle important dans la régulation dans la cellule A pancréatique chez le rat hyperinsulinémique chronique.

Mots clés : glycémie, insuline, glucagon, somatostatine, lipoprotéine de très faible densité (VLDL).

[Traduit par la rédaction]

\footnotetext{
${ }^{1}$ Author to whom reprint requests should be addressed.

2Present address: 2nd Department of Medicine, Kobe University Medical School, Kobe, Japan.

${ }^{3}$ Present address: Showa University Medical School, Tokyo, Japan.
} 


\section{Introduction}

The regulation of secretion of pancreatic glucagon is a complex phenomenon mediated by interactions between endocrine, neurocrine, and metabolic factors (Unger et al. 1978). In the rat, the anatomic juxtaposition of $A$ and $D$ cells around $a B$ cell core (Orci 1976) has led to the classic proposal that glucagon secretion may also be modulated in a paracrine fashion by insulin and (or) somatostatin (Unger and Orci 1977). Quantitative electron microscopic autoradiography has demonstrated that radiolabelled insulin binds to only $35 \%$ of the islet A cell population, while somatostatin binds $75 \%$ of the A cells (Patel et al. 1982; Amherdt et al. 1987). Radioreceptor analysis of purified populations of rat A cells has demonstrated these cells to be sensitive to somatostatin (Schuit et al. 1989), but to be largely devoid of high-affinity receptors for insulin (Van Schravendijk et al. 1985). Furthermore, it has been reported that insulin does not modulate basal or nutrient-stimulated glucagon release from purified normal rat A cells (Pipeleers et al. 1985). These in vitro data suggest that, in nondiabetic rats, pancreatic glucagon release may not be sensitive to direct inhibition by insulin. By contrast, a number of reports have indicated that the situation may be different in diabetic animals, in which acute or chronic exposure to insulin can suppress glucagon release (Weir et al. 1976; Braaten et al. 1974; Patel 1983a, 1983b). These in vivo data suggest that the regulation of glucagon secretion may be at least indirectly dependent on prevailing long-term insulin concentrations.

To establish whether chronic insulin is capable of suppressing the plasma levels of glucagon in nondiabetic rats in vivo, glucagon concentrations were followed in normal rats made chronically hyperinsulinemic. Rats were used as the experimental animal in these studies to avoid complications owing to nonpancreatic sources of glucagon. The rat (Kervran et al. 1987), in contrast with the dog (Doi et al. 1979), has little extra-pancreatic glucagon. The insulin was delivered either endogenously from the pancreas in response to oral sucrose supplementation or exogenously from osmotic minipumps implanted either subcutaneously (s.c.) or intraperitonealy (i.p.). The two routes of exogenous insulin administration were selected to mimic normal portal - peripheral insulin gradients (i.p.) or the subcutaneous administration of insulin in insulin-treated diabetics (s.c.) (Kazumi et al. 1986a). Our models have the advantage of establishing chronic hyperinsulinemia from both endogenous and exogenous sources in normal rats, in contrast with the studies of other investigators in which insulin-glucagon interactions were mainly studied using diabetic animals (Weir et al. 1976; Braaten et al. 1974; Patel 1983a, 1983b) or using pancreata made acutely hypoinsulinemic by immunoneutralization (Maruyama et al. 1984; Samols et al. 1988; Samols and Stagner 1988). The results of the present study indicated that the rat pancreatic A cell was remarkably insensitive to suppression by chronic hyperinsulinemia. To establish whether the rat A cell was sensitive to suppression by factors other than insulin, we also examined the effects of acute somatostatin infusion with and without hyperinsulinemia and hyperglycemia.

\section{Materials and methods}

Rats

Male Wistar rats were individually housed in metal cages in a temperature- and humidity-controlled room for 7 days prior to use. All animais were fed rat chow (Ralston Purina Co., St. Louis, MO) ad libitum.

\section{Experimental protocols}

Chronic hyperinsulinemia

To establish whether plasma glucagon levels are suppressed by hyperinsulinemia, four groups of animals were studied: two were sham operated on day 0 and allowed to recover and two (s.c., $n=$ 17; and i.p., $n=17$ ) had exogenous insulin delivered through osmotic minipumps implanted on day 0 . One of the sham-operated groups served as a control and had normal drinking water (controls, $n=10$ ). The other sham-operated group (sucrose fed, $n=10$ ) was given free access to a $10 \%(\mathrm{w} / \mathrm{v})$ sucrose drinking solution to stimulate secretion of endogenous insulin. Rats treated with exogenous insulin had osmotic minipumps (model 2002, Alza Corp., Palo Alto, CA) implanted either subcutaneously (s.c.) in the interscapular region or into the peritoneal cavity (i.p.). Regular purified porcine insulin (500 U/mL, Eli Lilly \& Co., Indianapolis, IN) was infused continuously at a rate of $6 \mathrm{U} /$ day for 14 days. L-Glutamic acid $(7 \mathrm{mg} / \mathrm{mL}$, Sigma) was added to the insulin solution to prevent insulin aggregation (Bringer et al. 1981). Drinking water for this group of rats was supplemented with $10 \%(\mathrm{w} / \mathrm{v})$ sucrose in an effort to prevent hypoglycemia. Blood $(1.5 \mathrm{~mL})$ was sampled from the tails of conscious rats at $24 \mathrm{~h}$ and 5,9 , and 14 days after implantation of the minipumps or sham surgery. Each rat was bled on two to three occasions including the final sampling on day 14. Rat chow was removed $18 \mathrm{~h}$ prior to blood sampling, but animals had continued free access to drinking water (with or without sucrose, as appropriate).

\section{Acute somatostatin administration}

To determine whether plasma glucagon levels could be suppressed by factors other than insulin, somatostatin was administered to normal rats. Two different protocols were used. In all experiments, rats were anaesthetized with pentobarbital $(65 \mathrm{mg} / \mathrm{kg})$, and infusion and sampling cannulas were inserted into the femoral veins. In the first protocol, basal samples $(1.5 \mathrm{~mL})$ were taken at -10 and $0 \mathrm{~min}$. Saline $(n=4)$ or somatostatin $\left(100 \mu \mathrm{g} \cdot \mathrm{kg}^{-1} \cdot \min ^{-1} ; n=6\right)$ were then infused for $45 \mathrm{~min}$ and blood samples $(1.5 \mathrm{~mL})$ were taken at +30 and $+45 \mathrm{~min}$. In the second protocol, following a similar basal sampling period, insulin was infused $\left(4 \mathrm{mU} \cdot \mathrm{kg}^{-1} \cdot \mathrm{min}^{-1}\right)$ and plasma glucose was clamped at hyperglycemic levels by concomitant infusion of glucose $\left(8 \mathrm{mg} \cdot \mathrm{kg}^{-1} \cdot \mathrm{min}^{-1}\right)$ for $45 \mathrm{~min}$. Saline $(n=6)$ or somatostatin $\left(50 \mu \mathrm{g} \cdot \mathrm{kg}^{-1} \cdot \min ^{-1} ; n=6\right)$ were also infused during the $45-\mathrm{min}$ clamp period. Blood samples $(1.5 \mathrm{~mL})$ were collected at 30 and $45 \mathrm{~min}$ after initiation of infusion.

\section{Assays}

Blood was collected into heparinized tubes for insulin and glucose determinations and into tubes containing $10 \%(\mathrm{v} / \mathrm{v})$ aprotinin (500 KIU/mL, Trasylol; FBA Pharmaceuticals, New York) and EDTA $(1.2 \mathrm{mg} / \mathrm{mL})$ for glucagon determination. Samples were centrifuged at $4{ }^{\circ} \mathrm{C}$ and plasma was stored at $-20^{\circ} \mathrm{C}$ prior to analysis.

Insulin was measured by radioimmunoassay (Herbert et al. 1965) using porcine and rat insulin as standards for rats receiving exogenous insulin and rats exposed only to endogenous insulin, respectively. The coefficient of variation of the assay was $10 \%$ and the range of the assay standard curve was $2.2-90 \mathrm{mU} / \mathrm{L}$. In 2 of the 34 insulin-treated rats, nonspecific insulin binding by the plasma was 2 standard deviations greater than in controls. Plasma insulin levels were therefore not measured in these two rats.

Plasma glucagon was determined by radioimmunoassay (Faloona and Unger 1974) using 30K antiserum (Dr. R. H. Unger, Dallas, TX), which cross-reacts with the free carboxyterminal end of glucagon and related moieties. The coefficient of variation of the assay was $12 \%$ and the range of the assay standard curve was $20-2000 \mathrm{ng} / \mathrm{L}$. Data from our laboratory have indicated that approximately $90 \%$ of total plasma glucagon immunoreactivity corresponds to 3500 molecular weight glucagon following HPLC analysis of plasma from normal male Wistar rats (J. N. Roberge and P. L. Brubaker, unpublished data).

The accuracy of the glucagon and insulin assays at low sample concentrations were further assessed by assay of known peptide concen- 
trations obtained by dilution of normal rat plasma. Glucagon values of 23,36 , and $50 \mathrm{ng} / \mathrm{L}$ were obtained for known concentrations of 33,50 , and $67 \mathrm{ng} / \mathrm{L}$, an underestimation of $27 \pm 4 \%$, while insulin values were underestimated by only $2 \%$ at 3.9 and $7.8 \mathrm{mU} / \mathrm{L}$ insulin. Thus, both assays were capable of detecting low levels of plasma glucagon and insulin $(33 \mathrm{ng} / \mathrm{L}$ and $3.9 \mathrm{mU} / \mathrm{L}$, respectively); however, the accuracy of the glucagon assay diminished at the low concentrations.

\section{Statistical analysis}

All data are expressed as mean \pm SEM. For the chronic hyperinsulinemia studies, comparisons were made with all of the time points together in each group using the Tukey's Studentized range test with a general linear model and an alpha value of $p<0.05$ on a Statistical Analysis System package for personal computers (SAS Institute Inc., Cary, NC). Plasma insulin values were log transformed prior to analysis as variances between groups were not equal. Analysis of variance for acute somatostatin administration studies and Pearson correlation coefficients were also determined using SAS.

\section{Results}

Body weights of rats were $340 \pm 4 \mathrm{~g}$ on day 0 and increased to $394 \pm 4 \mathrm{~g}$ over the 14-day experimental period. No differences between control rats and sucrose-fed or insulin-treated rats could be detected, as previously observed (Kazumi et al. 1985, 1986a, 1986b; Martin et al. 1983).

Sucrose supplementation of drinking water in noninsulintreated (sucrose fed) rats significantly elevated plasma glucose levels above those seen in other groups (Fig. 1). In contrast, plasma glucose levels of insulin-treated, sucrose-supplemented rats (i.p. or s.c.) were not significantly different from those of control rats. In keeping with the glucose ingested by sucrosefed rats, there was significant hyperinsulinemia; this was, however, inadequate to overcome the hyperglycemia in these animals. The elevation of endogenous plasma insulin levels in sucrose-fed rats was comparable with that seen in i.p. insulintreated rats; however, both sucrose-fed and i.p. rats had peripheral venous insulin levels that were significantly lower than that seen in s.c. insulin-treated rats (Fig. 1). The difference in insulin levels between the i.p. and s.c. insulin-treated rats has been attributed to hepatic extraction of a large fraction of the i.p. administered insulin before it reached the systemic circulation (Kazumi et al. 1986a). Despite the hyperglycemia and the endogenous hyperinsulemia in the sucrose-fed rats, plasma glucagon levels were not suppressed when compared with those of control rats (Fig. 1). Furthermore, plasma glucagon concentrations in the insulin-treated rats were significantly greater than those found in control animals. Thus, there appeared to be a lack of suppression of plasma glucagon by chronic hyperinsulinemia in all rats. Interestingly, although no differences between the peripheral insulin levels of i.p. and sucrose-fed rats were detected, plasma glucagon levels were lower in sucrose-fed animals. This may have been the consequence of the significantly higher plasma glucoses seen in sucrose-fed rats.

The possible separate effects of insulin and glucose on plasma glucagon concentrations were examined by correlation analysis (Fig. 2) of the individual data from Fig. 1. Regardless of the route of exogenous insulin administration, rats with the highest plasma levels of insulin were found to have hypoglycemia when compared either with control or with sucrose-fed animals. Those insulin-treated rats with less severe hyperinsulinemia had significant hyperglycemia. Thus there was, as expected, an inverse relationship between plasma levels
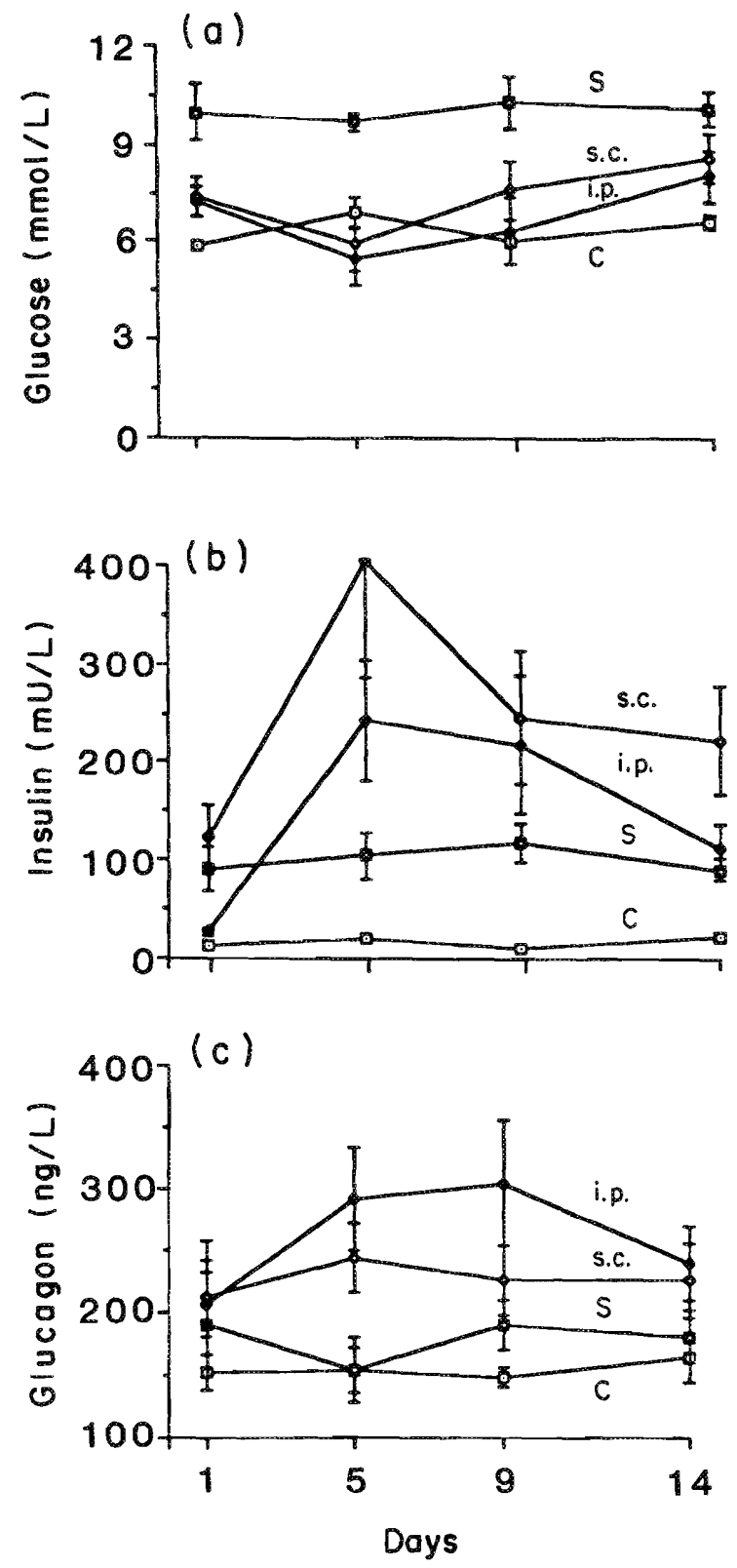

FIG. 1. Changes in plasma glucose, insulin, and glucagon in control rats $(C)$ or in response to sucrose feeding $(S)$ or exogenous administration of insulin (s.c., subcutaneous; i.p., intraperitoneal). Significant differences between groups, determined at an alpha value of $p<0.05$, were found for the following: $(a)$ glucose: S vs. s.c., i.p., and $C ;(b)$ insulin: s.c. vs. i.p., S, and $C$, and i.p. vs. C; and (c) glucagon: i.p. vs. S and C, and s.c. vs. C.

of insulin and glucose $(n=65 ; r=-0.42, p<0.0001$; Fig. 2a). A similar correlation $(n=73 ; r=-0.46, p<$ 0.0001 ) was obtained for the relationship between glucose and glucagon (Fig. $2 b$ ), as rats that were hypoglycemic were found to be hyperglucagonemic, whereas in rats with normo- or hyper-glycemia glucagon levels were lower. Interestingly, hyperglycemia did not suppress glucagon levels below those seen in normoglycemic rats. In contrast with the inverse relationships between glucose and insulin or glucagon, the plasma levels of glucagon and insulin were found to change concomitantly (Fig. 2c). A significant correlation between insulin and gluca- 

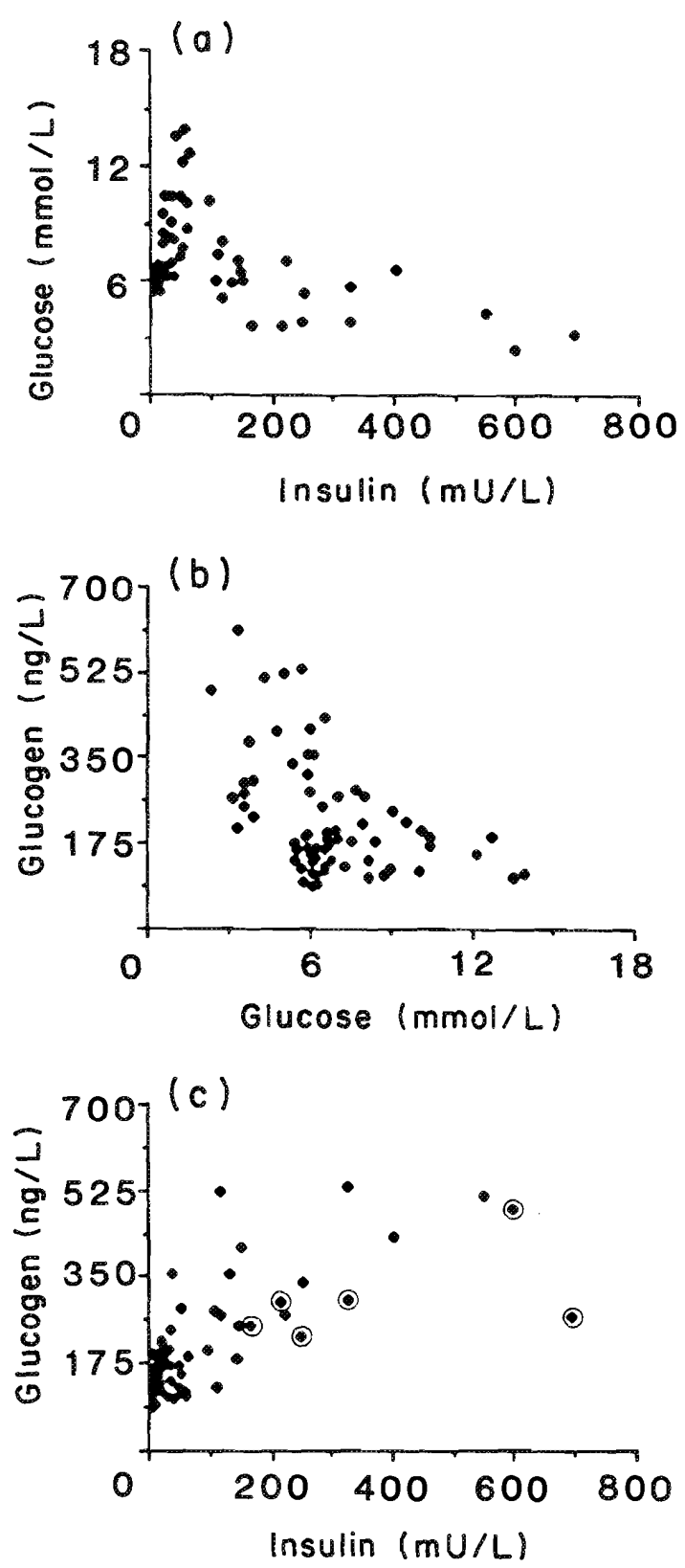

FIG. 2. Relationships between plasma insulin and glucose $(a)$, glucose and glucagon $(b)$, and insulin and glucagon $(c)$. The data points were taken from the individual data that were pooled and shown as mean values in Fig. 1. Data points that are circled indicate those animals with blood glucose levels of less than $3.9 \mathrm{mmol} / \mathrm{L}$.

gon was noted whether hypoglycemic animals were included in the analysis $(n=65 ; r=0.47, p<0.0001)$ or not $(n=$ $59 ; r=0.47, p<0.0001)$.

To establish whether pancreatic glucagon secretion could be suppressed below basal by factors other than insulin or glucose, saline or a high dose of somatostatin was administered both to unclamped rats and to hyperinsulinemic, hyperglycemic clamped rats. In both sets of animals (Figs. 3 and 4), basal insulin levels were higher than those seen in Fig. 1. This difference may reflect a response to anaesthesia and (or) surgery as compared with the conscious animals used for Fig. 1. In unclamped rats, the plasma levels of glucose in somatostatin-infused rats were the same as in saline-infused controls; however, somatostatin
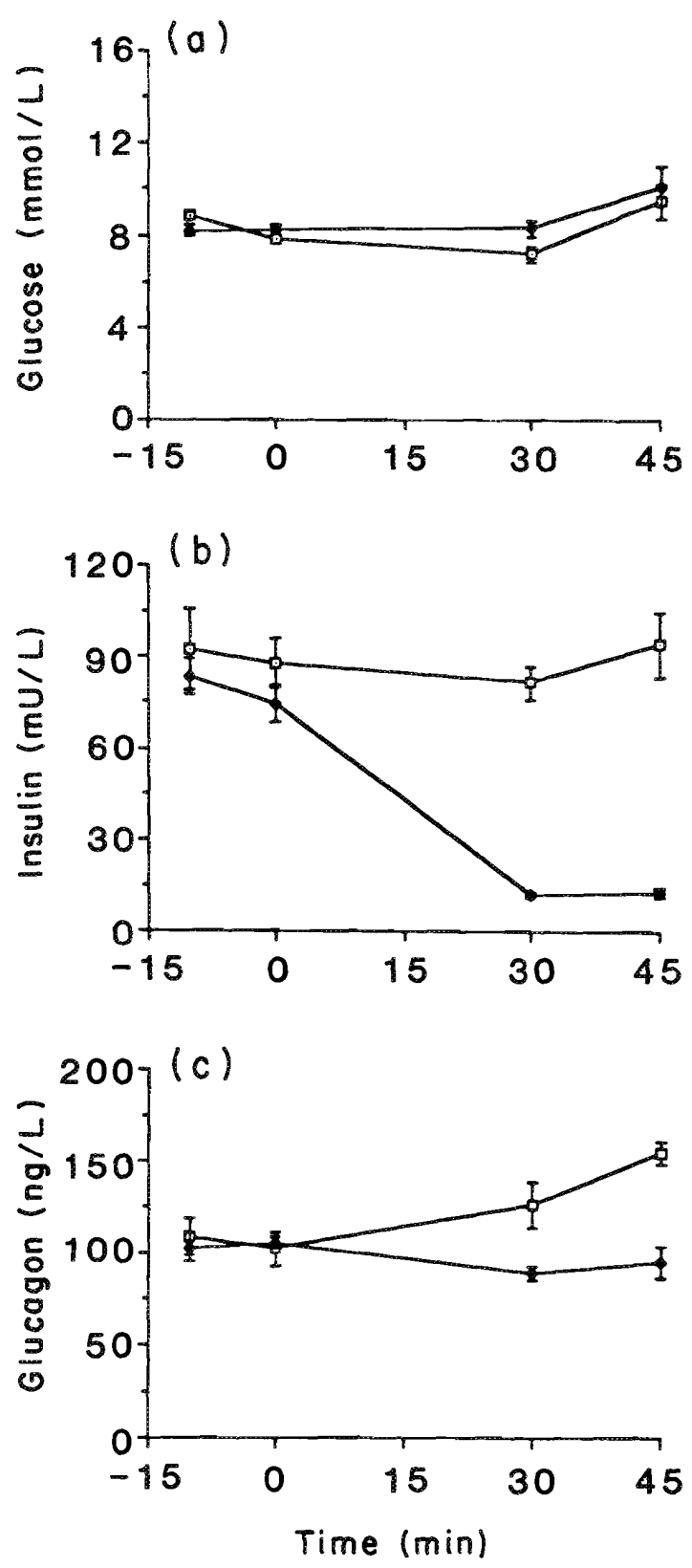

Fig. 3. Plasma (a) glucose, $(b)$ insulin, and $(c)$ glucagon responses to acute infusion (from $t=0$ to $t=45 \mathrm{~min}$ ) of saline ( $\square$ ) or somatostatin (). Significant differences between the responses to infusion of saline and somatostatin were found for insulin $(p<0.0001)$ and glucagon $(p<0.001)$.

markedly suppressed the plasma levels of insulin (Fig. 3). In saline-infused animals, plasma glucagon levels rose above basal values $(p<0.005$ ). Glucagon levels did not change from basal during somatostatin infusion, however, indicating an inhibition of the increase in glucagon seen in saline-infused rats $(p<0.001)$. Thus, despite suppression of insulin by somatostatin, glucose levels were the same in saline- and somatostatin-infused rats. In the hyperinsulinemic, hyperglycemic clamp experiments (Fig. 4), plasma insulin and glucose were both clamped to eliminate the possible effects of differences in the levels of either on glucagon secretion. With the clamp, no differences in plasma glucose and insulin concentrations were found between saline- and somatostatin-infused 

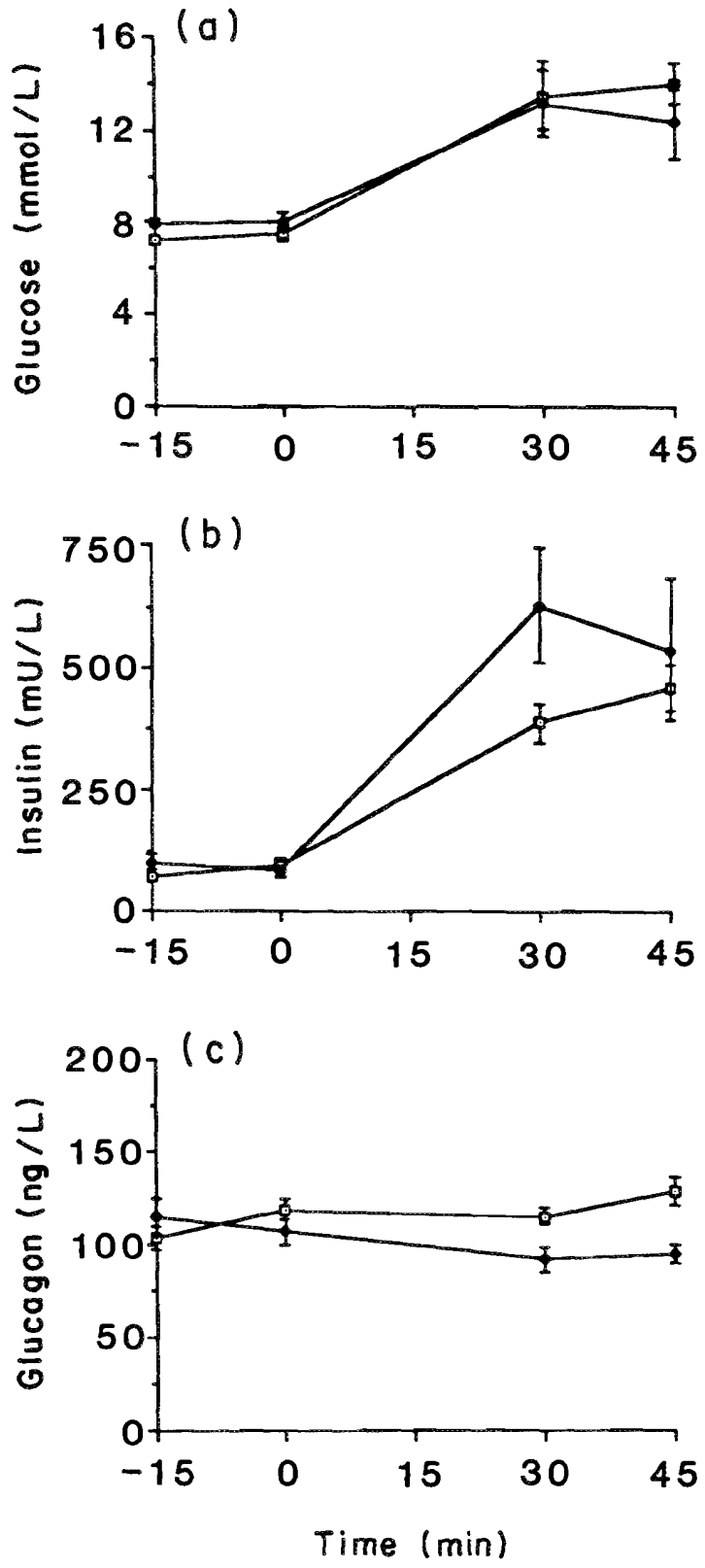

Frg. 4. Plasma (a) glucose, $(b)$ insulin, and $(c)$ glucagon responses to infusion (from $t=0$ to $t=45 \mathrm{~min}$ ) of saline ( $\square$ ) or somatostatin (a) in insulin-glucose clamped rats. Significant differences between the responses to infusion of saline and somatostatin were found for glucagon only $(p<0.007)$.

animals. In contrast with the unclamped animals (Fig. 3), plasma glucagon levels in saline-infused clamped animals did not rise significantly. Somatostatin infusion did cause plasma glucagon levels to fall slightly but not significantly below basal in clamped rats, however, so that glucagon levels in somatostatin-treated rats were again significantly lower than in saline controls $(p<0.007)$.

\section{Discussion}

The data presented in this report support the concept that, in the chronic hyperinsulinemic rat, factors other than insulin may play important roles in the regulation of pancreatic glucagon secretion. Induction of hyperinsulinemia through either stimulation of endogenous secretion or exogenous administration did not inhibit plasma glucagon levels below basal under either normo- or hyper-glycemic conditions. Elevated glucagon levels in hypoglycemic animals presumably reflected counterregulatory input resulting from neural stimulation (Frohman and Nagai 1976) and (or) epinephrine release (Weir et al. 1974). Interestingly, no negative correlation was found between plasma levels of insulin and glucagon in these rats, as suggested by many in vivo studies (Braaten et al. 1974; Patel 1983a, 1983b; Asplin et al. 1981, 1984; Service et al. 1978), and in contrast, an overall positive correlation between insulin and glucagon was observed. These results suggested a dissociation of glucagon release from direct modulation by insulin under conditions of either chronic endogenous or exogenous hyperinsulinemia in nondiabetic rats.

A number of investigators have examined the relationship between insulin and glucagon using a variety of conditions of insulinemia. Asplin et al. (1981) demonstrated that exogenous insulin inhibited glucagon release in C-peptide negative diabetics. Consistent with these results are reports of enhanced glucagon secretion in acutely insulin-deficient animals, even in the presence of hyperglycemia (Weir et al. 1976; Filipponi et al. 1986). In normal subjects, however, Asplin et al. (1981, 1984) found that acute administration of exogenous insulin inhibits endogenous insulin release and thereby stimulates glucagon secretion. Thus, the results of the present study are consistent with those of Asplin et al. $(1981,1984)$ and extend the observation of paradoxical stimulation of glucagon by exogenous hyperinsulinemia to include endogenous hyperinsulinemia. However, to explain our finding of a lack of inhibition of glucagon to levels below basal under conditions of endogenous hyperinsulinemia, and in hyperinsulinemia with hyperglycemia, it is necessary to invoke mediating factors, such as somatostatin for example. Specific receptors for somatostatin have been detected on a large number of the rat islet $A$ cell population (Patel et al. 1982; Amherdt et al. 1987; Van Schravendijk et al. 1985), whereas purified rat A cells have been reported to lack high-affinity receptors for insulin (Van Schravendijk et al. 1985). Thus, receptor population data would appear to favour paracrine modulation of glucagon release by somatostatin rather than by insulin.

Somatostatin infusion into both clamped and unclamped animals was demonstrated to inhibit plasma glucagon levels. The dose of somatostatin required to inhibit circulating pancreatic glucagon in rats $\left(100 \mu \mathrm{g} \cdot \mathrm{kg}^{-1} \cdot \mathrm{min}^{-1}\right)$ was much greater than the effective dose in dogs $\left(0.5 \mu \mathrm{g} \cdot \mathrm{kg}^{-1} \cdot \mathrm{min}^{-1}\right.$; Lickley et al. 1979) or humans $(200-\mu \mathrm{g}$ bolus plus $50 \mu \mathrm{g} / \mathrm{h}$; Lins et al. 1983), suggesting that the pancreatic A cell in the rat is less sensitive to inhibition by somatostatin than in other species. These results were surprising in view of reports that somatostatin binds to rat A cells (Patel et al. 1982; Amherdt et al. 1987) and inhibits rat glucagon secretion in vitro (Shuit et al. 1989; Mandarino et al. 1981). Furthermore, although somatostatin infusion in the rat did prevent increases in pancreatic glucagon in the present study, significant inhibition below basal levels could not be demonstrated. This was not due to an insensitivity of the rat glucagon radioimmunoassay, as the assay was sensitive to $30 \mathrm{pg} / \mathrm{mL}$. These results do raise the possibility, however, that high concentrations of somatostatin are required to suppress glucagon secretion below basal in the rat in vivo. This could be consistent with the high somatostatin concentration found within the islet and would 
support a paracrine effect of somatostatin on islet hormone secretion.

Inhibitory effects of insulin on the pancreatic content of somatostatin have been reported in diabetic rats (Papachristou et al. 1989) and dogs (Rastogi et al. 1990), although inhibitory effects on somatostatin release have been observed under some (Gerber et al. 1981; Patel et al. 1988) but not all (Gerber et al. 1981; Schauder et al. 1978) conditions. For example, insulin has been reported to inhibit glucose- and argininestimulated, but not basal somatostatin secretion (Gerber et al. 1981). Thus, our failure to detect any suppression of glucagon below basal levels in chronic hyperinsulinemic rats is not understood at the present time. One possibility, however, is that with chronic hyperinsulinemia, there is insulin-induced inhibition of somatostatin and a consequent failure of somatostatin to inhibit the rat $\mathrm{A}$ cell in a paracrine fashion. It cannot be discounted, however, that another yet to be identified factor might exist that is stimulated by hyperinsulinemia and which itself is stimulatory to glucagon secretion.

We have previously reported that chronic hyperinsulinemia is accompanied by an increase in very low density lipoprotein (VLDL) triglyceride production (Kazumi et al. 1985, 1986a, 1986b; Martin et al. 1983). Chronic hyperinsulinemia in those rats was induced using a protocol identical to that described in this paper. Although the rats were normoglycemic, it was possible that the chronic hyperinsulinemia had suppressed plasma glucagon levels. Hence, the altered VLDL kinetics theorectically could have been a consequence of the hyperinsulinemia and (or) hypoglucagonemia. Thus, we also wished to establish by the present study whether hypoglucagonemia existed and could have contributed to the increased VLDL turnover in hyperinsulinemic rats (Kazumi et al. 1985, 1986a, 1986b). Although it is known that hepatic lipogenesis is increased in glucagon-deficient states (Boyd et al. 1981), the present studies suggest that glucagon levels are not diminished in our chronic hyperinsulinemic model. Thus, glucagon is not involved in the increased VLDL triglyceride production seen in chronic hyperinsulinemia.

In summary, chronic physiologic or supraphysiologic levels of insulin did not decrease the circulating levels of glucagon in rats, and supraphysiologic levels of insulin increased glucagon levels independent of glycemia. The control of pancreatic A cell secretion in the chronic hyperinsulinemic rat is complex, therefore, and factors other than insulin may play an important role in the regulation of pancreatic A cell secretion.

\section{Acknowledgements}

We are grateful to $\mathrm{N}$. Kovacevic for excellent technical assistance. The work presented in this paper was supported by grants from the Medical Research Council of Canada, Canadian Diabetes Association, and Juvenile Diabetes Foundation International. P.L.B. was supported by a Scholarship from Diabetes Canada.

Amherdt, M., Patel, Y. C., and OrCI, L. 1987. Selective binding of somatostatin-14 and somatostatin-28 to islet cells revealed by quantitative electron microscopic autoradiography. J. Clin. Invest. 80: $1455-1458$.

Asplin, C. M., Paquette, T. L., and Palmer, J. P. 1981. In vivo inhibition of glucagon secretion by paracrine beta cell activity in man. J. Clin. Invest. 68: 314-318.

Asplin, C. M., Hollander, P. M., and Palmer, J. P. 1984. How does glucose regulate the human pancreatic $A$ cell in vivo? Diabetologia, 26: 203-207.
Boyd, M. E., Albright, E. B., Foster, D. W., and McGarry, J. D. 1981. In vitro reversal of the fasting state of liver metabolism in the rat. J. Clin. Invest. 68: 142-152.

Braaten, J. T., Faloona, G. R., and Unger, R. H. 1974. The effect of insulin on the alpha-cell response to hyperglycemia in long standing alloxan diabetes. J. Clin. Invest. 53: 1017-1021.

Bringer, J., Heldt, A., and Grodsky, G. M. 1981. Prevention of insulin aggregation by dicarboxylic amino acids during prolonged infusion. Diabetes, 30: $83-85$.

Dol, K., Prentki, M., Yip, C., Muller, W. A., Jeanrenaud, B., and VRANIC, M. 1979. Identical biological effects of pancreatic glucagon and a purified moiety of canine gastric immunoreactive glucagon. J. Clin. Invest. 63: 525-531.

Faloona, G. R., and Unger, R. H. 1974. Glucagon. In Methods of hormone radioimmunoassay. Edited by B. M. Jaffe and H. R. Behrman. Academic Press, New York. pp. 317-330.

Filipponi, P., Gregorio, F., Cristallini, S., Ferrendina, C., NicoletT, I., and SANTEUSANIO, F. 1986. Selective impairment of pancreatic $A$ cell suppression by glucose during acute alloxaninduced insulinopenia: an in vitro study on isolated perfused rat pancreas. Endocrinology (Baltimore), 119: 408-415.

Frohman, L. A., and NAGAI, K. 1976. Central nervous systemmediated stimulation of glucagon secretion in the dog following 2-deoxyglucose. Metab. Clin. Exp. 25 (Suppl. 1): 1449-1452.

Gerber, P. P. G., Trimble, E. R., Wollheim, C. B., and Renold, A. E. 1981. Effect of insulin on glucose- and arginine-stimulated somatostatin secretion from the isolated perfused rat pancreas. Endocrinology (Baltimore), 109: 279-283.

Herbert, V., LaU, K. S., Gotleib, C. W., and Bleicher, S. 1965. Coated charcoal immunoassay of insulin. J. Clin. Endocrinol. Metab. 25: 1375-1384.

KazUmi, T., VRanic, M., and Steiner, G. 1985. Changes in very low density lipoprotein particle size and production in response to sucrose feeding and hyperinsulinemia. Endocrinology (Baltimore), 117: $1145-1150$.

Kazumi, T., Vranic, M., Bar-ON, H., and Steiner, G. 1986a. Portal vs. peripheral hyperinsulinemia and very low density lipoprotein triglyceride kinetics. Metab. Clin. Exp. 35: 1024-1028.

KazUMI, T., Vranic, M., and Steiner, G. 1986b. Triglyceride kinetics: effects of dietary glucose, sucrose and fructose alone or with hyperinsulinemia. Am. J. Physiol. 13: E325-E330.

Kervran, A., Blache, P., and Bataille, D. 1987. Distribution of oxyntomodulin and glucagon in the gastrointestinal tract and the plasma of the rat. Endocrinology (Baltimore), 121: 704-713.

LICKLeY, H. L. A., Ross, G. G., and VRANIC, M. 1979. Effects of selective insulin or glucagon deficiency on glucose turnover. Am. J. Physiol. 236: E255-E262.

Lins, P. E., Wayngot, A., Adamson, U., Vranic, M., and EfenDIC, S. 1983. Minimal increases in glucagon levels enhance glucose production in man with partial hypoinsulinemia. Diabetes, 32: $633-636$.

Mandarino, L., Stenner, D., Blanchard, W., Nissen, S., Gerich, I., Ling, N., Brazeau, P., Bohlen, P., Esch, F., and Guillemin, R. 1981. Selective effects of somatostatin-14, -25, and -28 on in vitro insulin and glucagon secretion. Nature (London), 291: $76-77$.

Martin, C., Desai, K. S., and Steiner, G. 1983. Receptor and postreceptor insulin resistance induced by in vivo hyperinsulinemia. Can. J. Physiol. Pharmacol. 61: 802-807.

Maruyama, H., Hisatomi, A., Orci, L., Grodsky, G. M., and UNGER, R. H. 1984. Insulin within islets is a physiologic glucagon release inhibitor. J. Clin. Invest. 74: 2296-2299.

ORCI, L. 1976. The microanatomy of the islets of Langerhans. Metab. Clin. Exp. 25(Suppl. 1): 1303-1313.

Papachristou, D. N., Pham, K., ZingG, H. H., and Patel, Y. C. 1989. Tissue-specific alterations in somatostatin mRNA accumulation in streptozotocin-induced diabetes. Diabetes, 38: 752-757.

PATEL, D. G. 1983a. Effects of prolonged insulin treatment on blunted plasma catecholamine and glucagon increase during insulin hypo- 
glycemia in streptozotocin diabetic rats. Metab. Clin. Exp. 32: $377-382$.

1983b. Rate of insulin infusion with a minipump required to maintain normoglycemia in diabetic rats. Proc. Soc. Exp. Biol. Med. 172: 74-78.

Patel, Y. C., Amherdt, M., and OrCI, L. 1982. Quantitative electron microscopic autoradiography of insulin, glucagon, and somatostatin binding sites on islets. Science (Washington, D.C.), 217: $1155-1156$.

Patel, Y. C., Prakash, M. L. S., Papachristou, D. N., Molnar FARKAS, E., and PHAM, K. 1988. Insulin is a potent inhibitor of somatostatin secretion and mRNA accumulation in a somatostatinproducing islet tumor cell line. Diabetes, 37(Suppl. 1): 402A.

Pipeleers, D. G., Schuit, F. C., Van SchravendiJK, C. F. H., and VAN DE WINKEL, M. 1985. Interplay of nutrients and hormones in the regulation of glucagon release. Endocrinology (Baltimore), 117: $817-823$.

Rastogi, K. S., Lickley, L., Jokay, M., Efendic, S., and Vranic, M. 1990. Paradoxical reduction in pancreatic glucagon with normalization of somatostatin and decrease in insulin in normoglycemic alloxan diabetic dogs; a putative mechanism of glucagon irresponsiveness to hypoglycemia. Endocrinology (Baltimore), 126: 10961104.

SAmols, E., and Stagner, J. I. 1988. Intra-islet regulation. Am. J. Med. 85(Suppl. 5A): 31-35.

Samols, E., Stagner, J. I., Ewart, R. B. L., and Marks, V. 1988. The order of microvascular cellular perfusion is $B \rightarrow A \rightarrow D$ in the perfused rat pancreas. J. Clin. Invest. 82: 350-353.
Schauder, P., McIntosh, C., Panten, U., Arends, J., Arnold, R., Frerichs, H., and CreutzFeld, W. 1978. Dynamics of somatostatin and insulin release from isolated rat pancreatic islets: evidence for intraislet interactions between $B$ cells and $D$ cells. Metab. Clin. Exp. 27(Suppl. 1): 1211-1214.

Schuit, F. C., Derde, M. P., and Pipeleers, D. G. 1989. Sensitivity of rat pancreatic $A$ and $B$ cells to somatostatin. Diabetologia, 32: $207-212$.

Service, F. J., Nelson, R. I., Rubenstein, A. H., and Go, V. L. W. 1978. Direct effect of insulin on secretion of insulin, glucagon, gastric inhibitory polypeptide, and gastrin during maintenance of normoglycemia. J. Clin. Endocrinol. Metab. 47: 488-493.

UNGer, R. H., and ORCI, L. 1977. Hypothesis: possible roles of the pancreatic $\mathrm{D}$-cell in the normal and diabetic states. Diabetes, 26: $241-244$.

UNGer, R. H., DoBbs, R. E., and ORCI, L. 1978. Insulin, glucagon and somatostatin secretion in the regulation of metabolism. Annu. Rev. Physiol. 40: 307-343.

Van Schravendijk, C. F. H., Foriers, A., Hooghe-Peters, E. L., Rogiers, V., Demeyts, P., Sodoyez, J. C., and Pipeleers, D. G. 1985. Pancreatic hormone receptors on islet cells. Endocrinology (Baltimore), 117: 841-848.

Weir, G. C., Knowlten, S., and Martin, D. B. 1974. Glucagon secretion from the perfused rat pancreas: studies with glucose and catecholamines. J. Clin. Invest. 54: 1403-1412.

Weir, G. C., Knowlton, S. D., Atkins, R. F., McKennan, K. X., and MarTin, D. B. 1976. Glucagon secretion from the perfused pancreas of streptozotocin-treated rats. Diabetes, 25: 275-282. 